\title{
主題講演報告
}

\section{Pathophysiology of Motor Speech Disorders (Dysarthria)}

\author{
廣 瀬 肇
}

\section{1. はじめに}

第20回国際音声言語医学会においては, 4 題の official reports が企画されたが，筆者はこのうち “Pathophysiology of Motor Speech Disorders (Dysarthria): 運動性構音障害 (麻痺性構音障害) の病態生理”を担当 する機会を得た．なお，座長は英国の Hardcastle 教授 (Reading 大学) であった.この report の場合は, 開 会式の直後に行われたために, 他の official reports と 異なって, 発表に引続いて panel discussion が組まれ なかった. したがって日本音声言語医学会会員でこの reportに関係したのは筆者だけであるので, 編集委員会 の指示により, 敢て演者として発表の内容ならびに座長 のコメントを紹介してみたい.

\section{2. 報告の背景と狙い}

麻痺性構音障害という用語は, 従来 “神経系の障害に 基づくことばの障害”と定義されていた. 最近になって その定義は，より包括的なものとなり，現在では “こと ばの生成に関与する基本的な運動過程の障害に起因した 神経・筇制御機構の破綻に基づく一連の構音障害” と定 義されている.このような定義から，運動性または運動 障害性構音障害という呼称が広く行われるようになった のである.

さて運動性構音障害の診断については, 単にことばの 異常の有無を判定するだけであれば，患者のことばを耳 で聞いて容易に結論が出せる．ただし，ことばの異常の 性質についてさらに詳しく記述しようとなると，これは なかなか困難である.このような困難さはあるにして も, 聴覚的評価をある一定の心理尺度に沿って施行し, 病型分類や重症度の判定に役立てようとする試みが各国 で行われていることも事実である.

しかし, 本来運動性構音障害患者のことばは, 構音器
官の運動障害の結果として起こるものであるから, 熟練 運動としての構音運動パタンを解析することができれ ば, 構音の病態を探るらえで, さらに直接的なアプロー チとなると考えられる.

このような背景のもとに, 筆者らはこれまで構音動態 の記録・解析を行ら目的で各種の方式を開発してきた. 今回の報告の狙いは，これらの方式のらち代表的なもの を紹介し, 典型的な症例についての動態解析結果を示す ことにあり, あわせて構音運動に関連する中枢神経系の 各部位の機能について考察を加えることをめざした.

\section{3. 構音器官の動態解析方式}

筆者が紹介した動態解析方式としては，エックス線マ イクロビームシステム, ファイバースコ1プと組み合わ せた光電グロトグラフ, 超音波断層法, 位置 検出装 置 (PSD システム) および筋電図などがある.おのおの の方式についての説明は省略するが, 患者への侵襲を最 小限にとどめ, しかも計算機によるデータ処理システム などを活用して多量の計測データを有効に収集できるよ らな考慮が払われている.

これらの方式のらち, 光電グロトグラフは発話中の声 門動態の解析に用いられ, 他の方式は付属管腔内の諸器 官の動態の解析に応用された. とくに筋電図は, 個々の 器官の運動に関与する筋のレベルでの制御様式を観察す るのに有用であった.

構音運動パタンの記録に際しては, 被験者に主として 日本語単音節の繰り返し発音行わせた. これは発音動作 として比較的単純なものであるが, 各種の疾患の特徴抽 出にはきわめて有用と考えられた.

\section{4. 研究結果の要約}

今回検討した疾患は, 小脳性失調症, パーキンソン症 候群, 筋萎縮性側索硬化症, 仮性球麻痺で, これらの症 
例の構音運動パタンを正常例と比較した。なお，特殊な 例として, 重症筋無力症の筋活動様式も検討した.

これらの症例について一般的にいえることは，口唇， 舌などにみられる運動パタンの異常が原疾患の運動異常 の性質を反映する傾向があるということである.

小脳性失調症の例では, 各器官上の 1 点の動きについ てみると，その運動範囲が不揃いで恒常性がなく，運動 の方向転換が円滑にいかない傾向がある．このような非 恒常性は各点の運動速度についても観察された．また運 動の開始から運動速度が最大になるまでの時間は，正常 人の場合運動範囲に関倸なく，ほぼ一定であるのに，小 脳性失調症ではこの值にバラツキがあり, しかも一般に 最大速度達成までに時間が掛かる傾向を認めた。これら の結果から，小脳性失調症では筋力発現の時間的要素に 異常があり，これが構音の異常を特徴づけていると推論 された.

パーキンソン症候群の症例では, 運動の繰り返し頻度 などは正常人とほとんど変わらないが，運動の範囲がか なり急速に減衰し運動が速く小刻みになってしまうとい う，四肢でみられる，いわゆる促進現象が認められるこ とが注目された.一方, パーキンソン症候群では, 臨床 的に筋の固縮 (強剛) によって運動が制限されることが 知られているが，喉頭を含む構音器官について機能的捛 抗筋相互の相反性制御に破綻があることが，筋電図学的 に確認された. また，パーキンソン症候群症例によくみ られる吃様症状に対応して, 声門部の動態に異常を認め ることも，光電グロトグラフによって明らかになった.

筋萎縮性側索硬化症および仮性球麻瘦症例は少なくと も構音の面では類似した運動パタンを示し，一般に繰り 返し運動の規則性は保たれているが各器官の運動は遅 く, 易疲労傾向が認められた. 筇萎縮性側索硬化症の例 で, 喉頭レベルにおける痤性の緊張六進のため, 発話中 に強い声門閉鎖が起こりやすいことも観察された.

\section{5. 中枢神経系の各部位の機能と運動性構音障害}

先にも述べたように，この報告の主要な狙いは，中枢 神経系各部の機能ならびにその障害と構音異常の関係を 検討することにあった. そこで，この項では上にあげた 代表的な疾患を中心に述べる.

まず小脳の機能について，いわゆる失調性構音障害に 関連づけて考えてみたい. 従来, 小脳外側部は運動のプ ログラミングや長期的な運動企画に関与すると考えられ て来た. しかもその機能は主として, 学習や過去の経験 を基盤としたものであるとされている.

いま，大脳連合野において，小脳外側部（すなわち半 球部）と大脳基底核の関与のもとに運動が企画される
と，大脳皮質運動野から，運動指令が錐体路を経て下行 していく.

この時点で，小脳中間部は，運動指令の再調整に重要 な働きを演ずる，すなわち，小脳は錐体路を下降する運 動指令を受入れ，もし，これに調整すべき点があれば, その情報をまだ運動指令が末梢に達する前に大脳半球へ 送り返し，そこで指令の内容をただちに修正できるよう にする機能を持つと考えられている.

さらに時間が過ぎると, 未梢で筋収縮が起こり, それ に引き続いて皮膚や関節や筋からのフィードバック情報 も中枢へ送られてくる.

結局のところ, 最初鉜錐体路を下降していく運動指令 は，いわば暫定的な性質をもったもので，末梢からのフ ィードバックによって常に修正を受けているばかりでな く，いわゆる大脳一小脳連関を介して絶えず再調整を受 けることになる.

小脳障害患者にみられる随意運動の異常は小脳が持つ プログラミング機能および再調整機能の破綻として理解 することができる，とくに，構音のような精妙な熟練運 動においては, 再調整機構の異常によって著しい障害が 引き起こされると考えられ，方向交代性の運動では素早 い方向転換が不可能になるといってよかろう.

このように考えてくると，小脳性失調患者にみられる 構音の破綻症状は, 主として小脳の再調整機能の障害に よってもたらされるものと推論することができる.

臨床的に, パーキンソン症候群は大脳基底核の機能障 害によって起こると考えられている. 病理組織学的に, パーキンソン症候群に特徵的な異常は, 黒質およびその 他のメラニン含有核の変性であるが, 近年の生化学的研 究によって，錐体外部系には，ドーパミンを始めとする 神経伝達物質が豊富に存在することが明らかになってき た. ドーパミンの久乏によって運動減少症状や筋強剛, さらには振戦が起こることが知られており，しかもこれ らの症状は，すべてパーキンソン症候群に特徵的であ る.

これまでパーキンソン症候群症例では発音が不正確と なり, 症例によっては, 発話速度が異常に速くなること が報告されている. 本研究で得られた結果は, このうち 後者に相当するものといえよう.

このよらに繰り返し動作がだんだん速くなる現象は， 促進現象などと呼ばれており，中枢神経系の固有振動機 構の抑制が解除された異常な状態であると考えられる. 大脳基底核の機能はまだ十分に解明されているとはいえ ないが，大脳基底核は大脳皮質に抑制的な働きを持って おり, 促進現象は, この抑制機能の障害を示唆するもの であろう。 
また，パーキンソン症候群における運動範囲の減少に よる運動抑制症状は, 拮抗筋間の相反性調節の破綻と関 連づけて考えることが可能と思われた。

筋萎縮性側索硬化症と仮性球麻疩を含むいわゆる麻痺 型の構音運動異常は，筋力の低下が基本となっている.

筋萎縮性側索硬化症および仮性球麻疩症例で最も目立 った所見は, 構音器官の運動範囲の縮小と, 発話速度の 低下および運動の易疲労性である. しかし多少の時間は 掛かっても個々の筋に十分な力が加われば，運動範囲は 十分に拡大する. また，運動範囲の面でも速 度の面で も，運動の恒常性はよく保たれている。

唇や舌の運動については, 顎の運動に依存する傾向が ある.これは他の疾患にも認められることがあり, 構音 運動障害があっても臨床的に㖽の運動性はかなりよく保 たれている例が多い.このような「澦運動への依存性」 は一種の代償性運動の発現とみることも可能であろう.

このような運動性の異常によって, 筋萎縮性側索硬化 症や仮性球麻疾を特徴づけるような子音の不正確性, 母 音の歪み, 発話速度の低下, 開鼻声, 鼻からの気流の洩 れなどが発症すると考えられる。この 2 つの疾患は, 神 経学的に区別されるべきものであり, 事実鑑別可能なも のであるが，少なくとも構音動態という点では，両者は かなり良く似ており，この意味では，構音動態の異常に

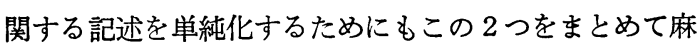
痺型として一括することが可能であると考えられた。

\section{6. 座長のコメントについて}

報告に引き続いて，座長の Hardcastle 教授からコメ
ントがあった.

コメントの冒頭に，まず本報告が，ことばの現象およ びその異常の現れ方について, 生理学的な拠り所を与え たことを評価するとの発言があった.

ついで研究方法のうち, 検查語として単音節を選んだ ことは構音運動パタンを単純化し, しかも解析結果を比 較する上できわめて適切であったと論評した. さらに解 析方法として今回の報告では言及されなかった電気的パ ラトグラフィの有用性を示唆した.

また今回の報告が，正常人においては正常発話のみを 記録しているが，正常人を対象としてバイトブロックな どを使用し，人工的異常状態における代償機能を観察す ることが，病的例の研究に資する可能性を述べた.

\section{7. 今後の課題一結語にかえて}

本研究の結果から, 構音の動的機構の研究を通じて, それぞれの神経疾患の基本的性質についてのさらに克明 な記述が可能となることが示唆され，また神経疾患の質 的ならびに量的評価も可能となっていくことが期待され る.

一方, 忘れてならないのは，今回の報告が，限られた 数の症例を対象にしたものであるということである.い ずれの症例も典型例ではあるが，運動パタンに個人差が あることも十分考慮に入れる必要があり，したがって今 後もこのような分析的研究をさらに多くの例について行 っていくべきであると考える. いずれにしても構音運動 とその障害について, さらに多くの神経生理学的研究が 積み重ねられていくことが必要である. 